\title{
PELATIHAN PEMBUATAN MEDIA PEMBELAJARAN MENGGUNAKAN APLIKASI ONLINE OPEN SOURCE GEOGEBRA DAN SCREEN RECORDER BAGI GURU-GURU SD NEGERI 17 KESIMAN
}

\author{
Wayan Sauri Peradhayana1, I Wayan Gede Wardika², I Kadek Adiana Putra ${ }^{3}$, I Putu \\ Surya Adi Putra ${ }^{4}$, I Made Dedy Setiawan ${ }^{5}$, Ni Wayan Suardiati Putri ${ }^{6}$ \\ 1,2,3,4,5,6 Program Studi Teknik Informatika, STMIK STIKOM Indonesia \\ e-mail: sauri.peradhayana@stiki-indonesia.ac.id", iwayangedewardika@stiki- \\ indonesia.ac.id ${ }^{2}$, adiana_putra@stiki-indonesia.ac.id ${ }^{3}$, suryaadiputra@stiki- \\ indonesia.ac.id ${ }^{4}$, dedy.setiawan@stiki-indonesia.ac.id ${ }^{5}$, suardiatiputri@stiki- \\ indonesia.ac.id ${ }^{6}$
}

\begin{abstract}
Abstrak
Pembelajaran disekolah dasar memerlukan media pembelajaran yang dapat memvisualisasikan materi pelajaran. Aplikasi yang bisa digunakan untuk membuat media pembelajaran diantaranya geogebra dan perekam layar. Pengabdian kepada masyarakat ini bertujuan untuk meningkatkan kemampuan guru dalam penggunaan aplikasi online open source geogebra untuk pembuatan media pembelajaran bidang matematika dan science, untuk meningkatkan kemampuan guru dalam penggunaan aplikasi online perekaman layar computer utuk pembuatan media pembelajaran pada pelajaran ilmu sosial. Metode yang digunakan adalah persiapan, pelaksanaan dan evaluasi. Simpulan yang dapat diambil yang pertama adalah adanya peningkatan kemampuan guru dalam penggunaan aplikasi online open source geogebra untuk pembuatan media pembelajaran bidang matematika dan science terlihat dari hasil mengenai pengetahuan, penggunaan dan pembuatan geogebra menjadi $100 \%$. Kedua, meningkatkan kemampuan guru dalam penggunaan aplikasi online perekaman layar computer utuk pembuatan media pembelajaran pada pelajaran ilmu social menjadi $100 \%$.
\end{abstract}

Kata kunci: geogerbra, media pembelajaran, perekam layar

\begin{abstract}
Learning in elementary schools requires learning media that can visualize the subject matter. Applications that can be used to create learning media include geogebra and screen recorders. This community service aims to improve the ability of teachers to use the open source geogebra online application for the manufacture of learning media in the fields of mathematics and science, to improve the ability of teachers to use computer screen recording online applications for making social studies learning media. The method used is preparation, implementation and evaluation. The first conclusion that
\end{abstract}


can be drawn is that there is an increase in the ability of teachers to use the open source application Geogebra online for making learning media in mathematics and science, seen from the results that $100 \%$ of teachers know, can use and can create learning media using geogebra. Second, improving the ability of teachers to use online computer screen recording applications, seen from the results that $100 \%$ of teachers know, can use and can create learning media using screen recording applications.

Keywords : geogebra, learning media, screen recorder

\section{PENDAHULUAN}

Perkembangan Teknologi belakangan ini semakin lama semakin meningkat. Banyak pakar Pendidikan memanfaatkan teknologi untuk mempermudah proses pembelajaran dengan pembuatan media pembelajaran. Media pembelajaran menarik dibahas karena memanfaatkan aplikasi online open source. Dengan memanfaatkan aplikasi online open source, maka media tersebut dapat digunakan dimana dan kapan saja baik oleh tenaga pengajar ataupun peserta didik. Belajar dapat dilakukan tanpa terhalang oleh waktu dan tempat, sehingga proses belajar akan menjadi lebih flexible lagi.

$$
\text { Pembuatan grafik pada }
$$

geogebra berdasarkan yang dipelajari siswa dapat diarahkan untuk membuat motif kain. Grafik yang telah dikembangkan untuk membuat motif kain Endek adalah Grafik fungsi kuadrat, linier dan trigonometri. Berdasarkan hasil penelitian penggunaan software geogebra pada pembuatan grafik fungsi kuadrat dan motif kain endek menggunakan langkah kerja pembuatan grafik fungsi kuadrat (Sauri, 2021).

Semua materi pembelajaran yang sangat memerlukan media pembelajaran. Pada siswa Sekolah Dasar, dimana siswa belum berfikir formal, ciri-ciri anak-anak pada tahap ini dapat memahami operasi logis dengan bantuan benda-benda konkrit. Sehingga pembelajaran yang cocok adalah menggunakan media pembelajaran. Salah satu media pembelajaran yang dapat dipilih adalah GeoGebra.

Pelatihan media pembelajaran dengan GeoGebra sangat membantu guru dalam membuat media pembelajaran seperti pelatihan yang dilakukan (Erawati, Purwati, Putri, \& Wardika, 2021). GeoGebra merupakan aplikasi gratis yang dapat diunduh lewat komputer, laptop, dan smartphone. GeoGebra adalah software yang memiliki sistem geometri dinamis, yang dapat mengkontruksikan sebuah titik, ruas garis, garis, vektor, bahkan fungsi dan dapat mengubahnya secara dinamis (Wardika \& Putra, 2019). Dengan memanfaatkan GeoGebra diharapkan proses pembelajaran menjadi lebih bermakna, sehingga hasil belajar dapat mendekati optimal.

Penelitian lainnya yang terkait dengan motif kain menyimpulkan bahwa penggunaan software geogebra pada pembuatan grafik fungsi linier dan 
motif kain endek menggunakan langkah kerja pembuatan grafik fungsi linier (Sauri 2020). GeoGebra dapat disandingkan dengan beberapa model pembelajaran, seperti TANDUR. Untuk model TANDUR berbantuan GeoGebra seperti penelitian yang dilakukan (Putri \& Wardika, 2020a) menghasilkan, bahwa model pembelajaran TANDUR berbantuan GeoGebra lebih baik daripada model pembelajaran konvensional. Selain itu, jika dilihat dari kemadirian belajar, seperti penelitian (Putri \& Wardika, 2020b) kemandirian belajar tinggi, rata-rata skor hasil belajar matematika yang dibelajarkan dengan model pembelajaran TANDUR berbantuan GeoGebra lebih baik daripada rata-rata skor hasil belajar matematika yang dibelajarkan dengan model pembelajaran konvensional. Disamping itu siswa dapat diarahkan untuk membuat motif kain endek melalui pembuatan fungsi trigonometri pada software geogebra. Hal ini berdasarkan hasil penelitian Sauri (2020), yang menyebutkan bahwa penggunaan software geogebra pada pembuatan grafik fungsi trigonometri dan motif kain endek menggunakan langkah kerja pembuatan grafik fungsi trigonometri.

Penggunaan aplikasi online tidak perlu dilakukan install pada komputer. Yang diperlukan adalah koneksi internet. Terkadang spesifikasi kompter yang dimiliki guru tidak sesuai kebutuhan program yang akan diinstall. Oleh sebab itu diperluka sebuah pemikiran baru, agar guru tidak perlu install agar komputer tetap stabil. Aplikasi online yang diperlukan terkait dengan visualisasi dan perekaman layar. Aplikasi online yang digunakan dlaam pelatihan ini adalah GeoGebra dan screen recorder. Geogebra diperlukan untuk visualiasi matematika, sedangkan screen recorder bisa digunakan untuk semua mata pelajaran.

Berdasarkan hasil wawancara dan observasi yang dilakukan dengan Kepala Sekolah dan beberapa guru di SD Negeri 17 Kesiman, Denpasar Timur, diketahui penggunakan Teknologi pada media pembelajaran belum maksimal. Hal ini terlihat dari sedikitnya guru-guru memanfaatkan teknologi untuk membuat suatu media ajar khususnya dalam visualisasi bentuk-bentuk geometri seperti bangun datar. Jika dalam keseharaian siswa dapat diperkenalkan langsung dengan bentuk nyatanya, maka akan lebih sulit dilakukan dalam kondisi daring. Oleh sebeb itu perlu kiranya guru-guru diberikan pelatihan terkait dengan penggunaan aplikasi yang bisa digunakan untuk memvisualisasikan bentuk-bentuk geometri tersebut. Salah satu aplikasi yang bisa digunakan adalah geogebra. Pada dasarnya geogebra digunakan sebagai pembuatan media pembelajaran terkait dengan geometri. Oleh sebab itu, pelatihan penggunaan geogebra sebagai alat bantu pembuatan media pembelajaran diperlukan oleh guruguru.

Hasil survey lainnya menunjukkan bahwa penugasan yang dilakukan melalui pesan singkat. Siswa memiliki kesulitan untuk memahami. Masih menurut hasil observasi, jika dilaksanakan pertemuan secara daring, maka siswa mengalami kendala pada 
ketersediaan jaringan internet. Oleh sebab itu diperlukan adanya media pembelajaran yang digunakan untuk dapat memberikan gambaran utuh mengenai pembelajaran. Salah satunya dalah pembuatan video pembelajaran menggunakan screen recorder. Menonton video akan menggunakan jaringan internet yang lebih sedikit dari pada melakukan tatap muka secara online. Guru juga sudah terbiasa membuat power point sebagai media pembelajaran. Oleh sebab itu akan mempermudah guru dalam mempersiapkan video, maka dirasa perlu melaksankan pelatihan pembuatan video dan memanfaatkan keahlian yang sudah dimiliki guru. Salah satu aplikasi yang digunakan adalah screen recorder. Screen recorder sama dengan guru melakukan presentasi dalam pembelajaran, guru hanya perlu merekam layar computer atau laptop dan kondisinya sama dengan persentasi.

Video memang menarik minat siswa dalam belajar. Alat perekaman juga memadai. Tidak semua guru memiliki perangkan yang cukup dalam melakukan perekaman video. Agar kendala perekaman dapat teratasi dan tetap dapat menghasilkan video, maka digunakan screen recorder. Screen recorder adalah sebuah aplikasi yang digunakan untuk merekam layar. Artinya guru sambil berbicara dan sambil melakukan presentasi power point dapat terekam. Hasil rekaman ini berupa video beserta suara dari guru.

Untuk itu perlu dipandang memberikan pelatihan pembuatan media pembelajaran menggunakan aplikasi online open source GeoGebra dan screen recorder bagi guru-guru SD Negeri 17 Kesiman, Denpasar Timur. Sehingga dengan dilaksanakan pelatihan ini diharapkan guru-guru mampu membuat media pembelajaran dari GeoGebra dan screen recorder untuk mendukung proses belajar mengajar. Hal ini akan membuat minat belajar siswa meningkat karena siswa dapat melihat secara langsung setiap materi yang sedang dibahas tanpa perlu membayangkan lagi.

Hasil observasi menunjukkan aktivitas belajar mengajar di SD Negeri 17 Kesiman berlangsung secara online. Obervasi awal pada bulan januari 2021 menunjukkan kelas-kelas kosong. Siswa melakukan pembelajaran jarakjauh (PJJ). Hanya ada beberapa guru yang memang ditugaskan secara bergiliran untuk datang ke sekolah.

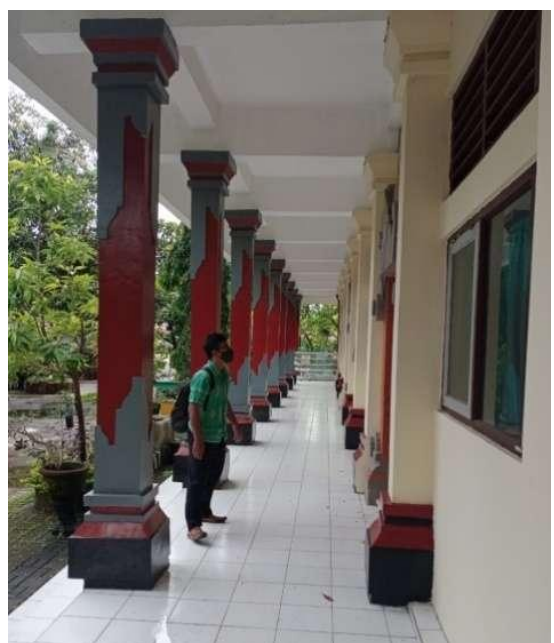

Gambar 1. Suasana Sekolah pada saat PJJ

Berdasarkan hasil observasi, banyak alat peraga yang mengarah 
kehidupan nyata atau benda seharihari. Visualiasi benda kongkrit sangat diperlukan pada perkembangan siswa SD. Untuk membantu siswa mengingat perkalian, juga dipasang bagan perkalian pada tangga. Jika dilihat dari situasi sehari-hari, siswa sangat terbantu untuk selalu mengingat perkalian.

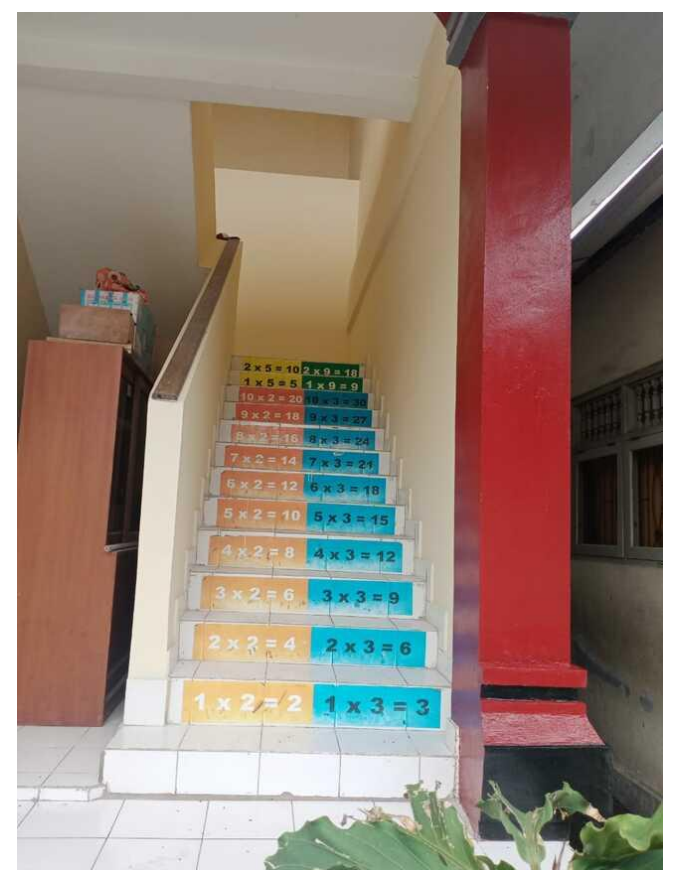

Gambar 2. Perkalian pada tangga

Observasi juga menunjukkan dukungan pada proses belajar mengajar sebetulnya sangat baik. Berbagai kreasi siswa bisa dikaitkan dengan banyak pelajaran seperti matematika, ilmu alam dan ilmu sosial. Namun situasinya berubah saat pandemi. Siswa tidak bisa melihatnya secara langsung. Segala sesuatu hanya bisa melalui online. Oleh sebab itu perlu adanya peningkatan kemampuan guru dalam menggunakan aplikasi online untuk membuat media pembelajaran.

Dari hasil wawancara dengan Kepala Sekolah SD Negeri 17 Kesiman, Denpasar Timur, belum ada guru yang menggunakan aplikasi online open source geogebra dan screen recorder. Dua aplikasi ini dapat membantu kinerja guru dalam mempersiapkan media pembelajaran.

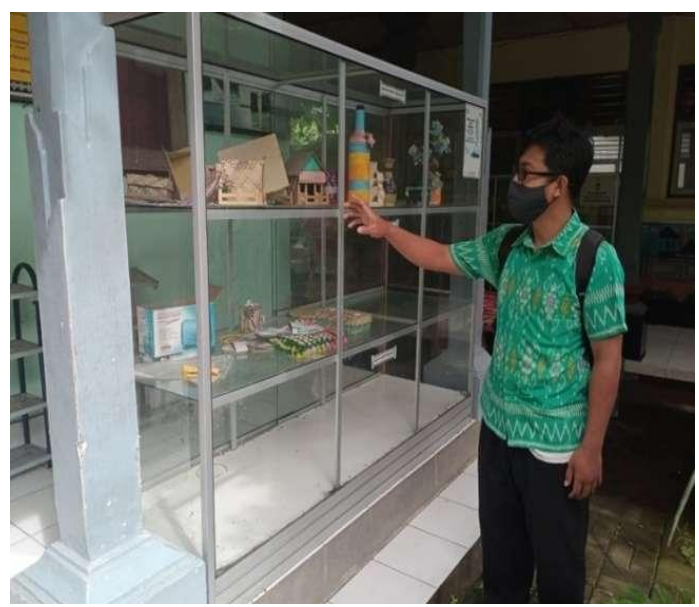

Gambar 3. Benda-benda konkrit

Berdasarkan latar belakang masalah di atas, maka dapat dirumuskan beberapa permasalahan, diantaranya: 1. Guru-guru di SD Negeri 17 Kesiman, Denpasar Timur, belum ada yang mengenal aplikasi open source geogebra, 2. Guru-guru di SD Negeri 17 Kesiman, Denpasar Timur belum ada yang mengenal aplikasi open source screen recorder.

Terkait dengan program pengabdian kepada masyarakat, STIKI memiliki program yang dinamakan STIKI Social Engagement (SSE) yang 
diadakan oleh Lembaga Penelitian dan Pengabdian pada masyarakat STIKI Indonesia (LPPM). SSE ini diharapkan mampu menjadi solusi atas kendala yang dihadapi di SD Negeri 17 Kesiman, Denpasar Timur, khususnya terkait dengan pemanfaatan teknologi untuk membuat media pembelajaran yang menarik bagi siswa, hal ini akan mendukung proses belajar mengajar menjadi lebih kondusif. Berdasarkan permasalahan yang telah diuraikan di atas, maka dapat diajukan beberapa solusi yang diharapkan nantinya dapat meningkatkan pemahaman dan pengggunakan GeoGebra dan screen recorder secara online dalam proses belajar mengajar.

Beberapa solusi yang dapat diberikan untuk menangani permasalahan yang dialami oleh Guruguru di SD Negeri 17 Kesiman, Denpasar Timur adalah kegiatan dengan sentuhan ipteks, yaitu:

1. Pengenalan aplikasi online open source GeoGebra.

2. Pengenalan aplikasi online open source Screen Recorder

3. Pelatihan pembuatan media pembelajaran dengan aplikasi online open source GeoGebra

4. Pelatihan pembuatan media pembelajaran dengan aplikasi online open source Screen Recorder

\section{METODE}

Adapun tahapan yang dilakukan dalam pelaksanaan kegiatan ini meliputi:

\section{Tahapan Persiapan}

Kegiatan tim pelaksana kegiatan pengabdian kepada masyarakat (PKM) pada tahap persiapan adalah melakukan observasi ke sekolah sasaran. Observasi dilakukan dengan wawancara kepada kepala SD 17 Kesiman. Observasi yang dilakukan untuk mengetahui permasalahan yang dihadapi guru dalam pembelajaran online khusunya bagaimana guru mempersiapkan media pembelajaran. Setelah diketahui permasalahan yang dihadapi mitra, selanjutnya disusun solusi yang bisa digunakan pada tahapan pelaksanaan.

\section{Pelaksanaan}

Tahapan kedua atau pelaksanaan kegiatan terbagi menjadi beberapa bagian, yaitu :

a. Pembinaan penggunaan aplikasi online open source geogebra dalam pembuatan media pembelajaran khusunya yang terkait matematika dan science

b. Pembinaan penggunaan aplikasi online perekaman layar computer dalam pembuatan media pembelajaran khususnya yang terkait dengan ilmu social.

c. Dilakukan kegiatan mandiri agar mitra dapat melatih kemampuannya dalam memanfaatkan aplikasi online

d. Presentasi untuk mengetahui sejauh mana peningkatan kemampuan mitra dalam membuata media pembelajaran berbasis aplikasi online.

\section{Evaluasi Kegiatan}

Tahap ke-tiga yaitu melihat tingkat keberhasilan pelaksanan pengabdian 
kepada masyarakat yang diusulkan ini akan dievaluasi selama pelaksanaan berjalan. Evaluasi awal dilakukan oleh tim pelaksana dalam dua hal kegiatan, yaitu:

a) Kegiatan inti merupakan kegiatan yang dilakukan saat diberikannya pembinaan, dan pendalaman.

b) Diluar kegiatan inti, yaitu kegiatan pendampingan yang dilakukan setelah tim pelaksana melaksanakan kegiatan pengabdian kepada masyarakat. Hal ini dilakukan untuk memastikan bahwa guru telah terampil dalam memanfaatkan aplikasi online dalam pembuatan media pembelajaran

\section{HASIL DAN PEMBAHASAN}

1. Pelaksaam Kegiatan

Kegiatan PKM dilaksanakan dalam 4 hari 17,18,19 dan 21 juni 2021. Kegiatan dilaksanakan secara luring bertempat di SD 17 Kesiman. Kegiatan PKM terdiri pmbinaan penggunaan Geogebra dan screen recorder. Pada hari pertama dilaksanakan kegiatan pembinaan pengenalan geogebra, pemberian materi media pembelajaran menggunakan geogebra pada sekolah dasar serta pelatihan penggunaan bagian-bagian gegebra. Pada hari kedua dilaksanakan kegiatan pelatihan pembuatan media pembelajaran menggunakan geogebra. Pada hari ketiga kegiatan yang dilaksanakan adalah pengenalan screen recorder, pemberian materi media pembelajaran menggunakan screen recorder pada sekolah dasar serta pelatihan penggunaan bagian-bagian screen recorder. Hari keempat dilaksanakan kegiatan pelatihan pembuatan media pembelajaran menggunakan screen recorder.

Pada saat pelaksanaan kegiatan hari pertama dibuka oleh kepala SD 17 Kesiman. Hari pertama kegiatan juga dilaksanakan survey berupa angket mengenai pengetahuan peserta tentang geogebra dan screen recorder. Pada hari terakhir dilaksanakan survey berupa angket mengenai kemampuan yang dimiliki peserta setelah melaksankan kegiatan. Setelah pengisisian survey, pada hari terakhir juga dilaksankaan penutupan kegiatan oleh Kepala SD 17 Kesiman. Hasil dari survey awal dan survey akhir akan dibahas tersendiri pada tahap evaluasi.

$$
\text { Kegiatan PKM juga }
$$

mengarahkan peserta agar membuat media pembelajaran menggunakan geogebra dan screen recorder secara mandiri. Hasil dari kegiatan mandiri akan dipaparkan pada bagian dokumentasi. Kegiatan berlangsung dengan menerapkan protokol kesehatan yang ketat. Seluruh peserta dan pelaksana kegiatan diwajibkan menggunakan masker dan mencuci tangan. Peserta yang terlibat dalam kegiatan PKM adalah 16 orang guru.

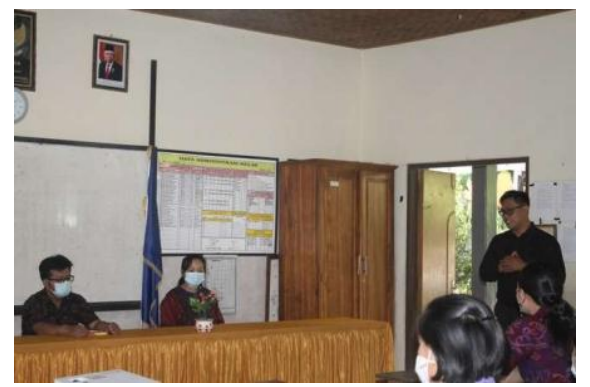

Gambar 4. Kegiatan pembukaan PKM 
Jurnal Widya Laksana, Vol.10, No.2, Agustus 2021

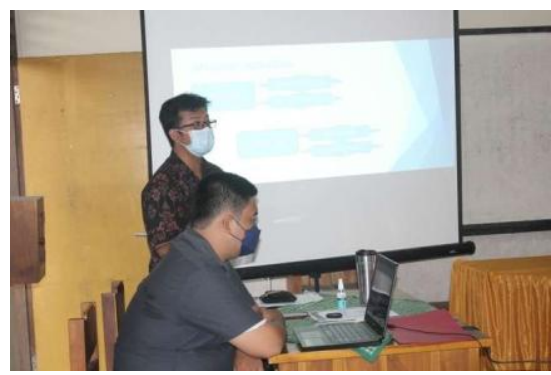

Gambar 2. Kegiatan pembinaan penggunaan Geogebra

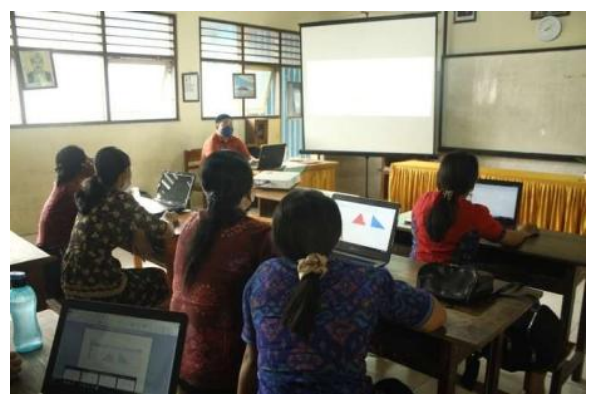

Gambar 5. Kegiatan pembuatan media pembelajaran menggunakan geogebra

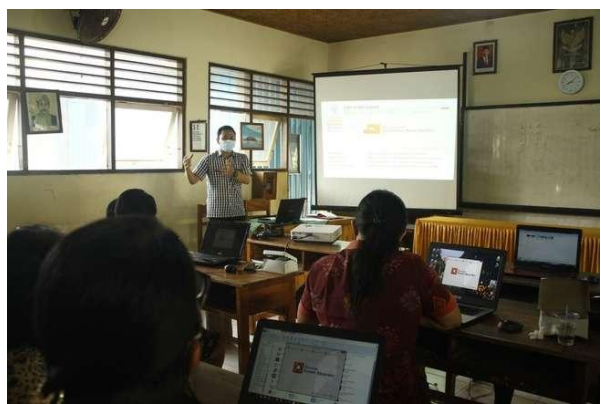

Gambar 6. Kegiatan pembinaan penggunaan screen recorder

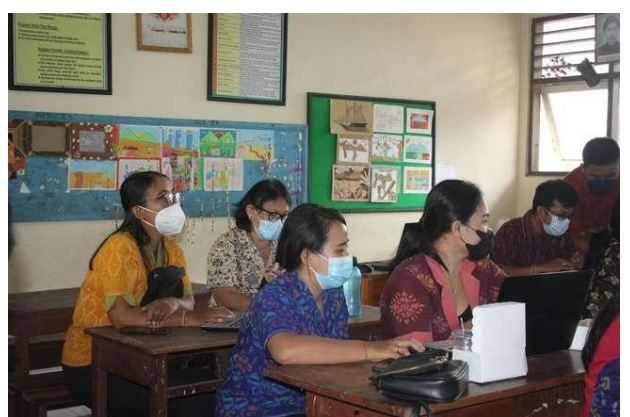

Gambar 7. Kegiatan Pembuataan Media pembelajaran menggunakan screen recorder

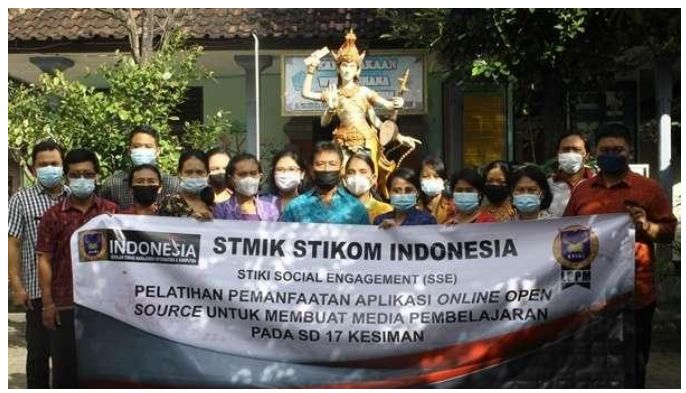

Gambar 8. Foto bersama

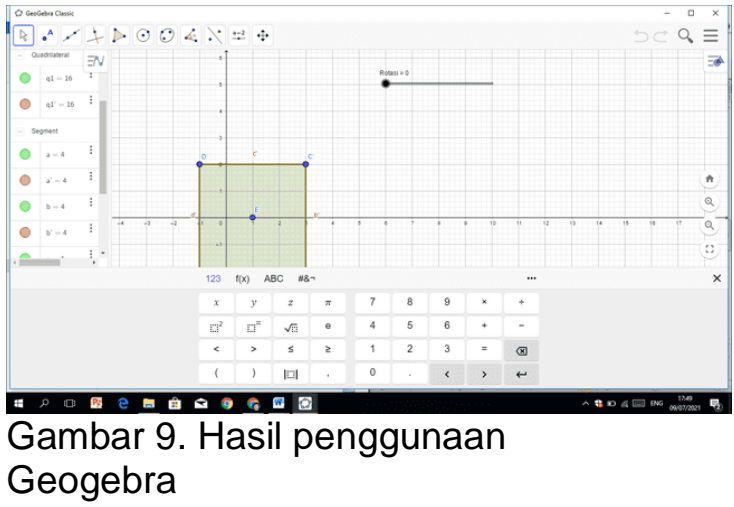




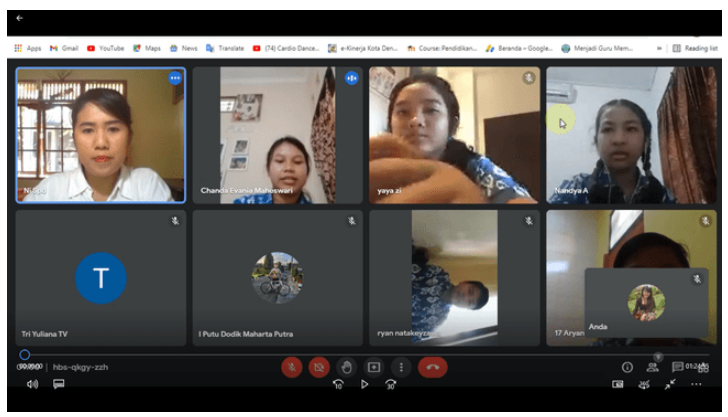

Gambar 10. Hasil penggunaan Screen Recorder

2. Evaluasi Kegiatan

a. Hasil pengisian angket pra pelatihan

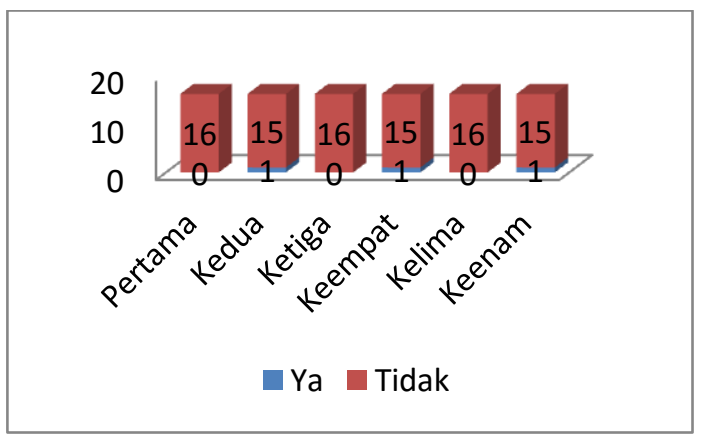

Gambar 11. Grafik Hasil pengisian angket pra pelatihan

Keterangan :

Pertama : Pengetahuan geogebra

Kedua : Pengetahuan tentang screen recorder

Ketiga : Penggunaan Geogebra

Keempat : Penggunaan Screen

Recorder

Kelima : Penggunaan geogebra dalm pembelajaran

Keenam : Penggunaan Screen recorder dalam pembelajaran

Untuk mengukur keberhasilan suatu kegiatan PKM dapat dilakukan dengan pre-tes dan post-test seperti (Putra dkk, 2021), atau menggunakan angket seperti PKM yang dilakukan (Wijayanti dkk, 2021). Pada PKM ini yang dipilih untuk menentukan keberhasilan suatu PKM adalah metode angket.

Angket yang disebar pra pelatihan terdiri jawaban ya atau tidak. Berdasarkan penyebaran angket dilakukan, dapat disimpulkan bahwa 16 atau $100 \%$ peserta belum mengetahui tentang geogebra, penggunaan geogebra dan penggunaan geogebra dalam pembelajaran. Sedangkan terdapat 1 orang atau $6,25 \%$ peserta sudah mengetahui screen recorder, penggunaan screen recorder dan penggunaan screen recorder dalam pembelajaran. Sedangkan sisanya yakni sebanyak 15 peserta atau $93,75 \%$ peserta belum mengetahui tentang screen recorder, penggunaan screen recorder dan penggunaan screen recorder dalam pembelajaran.

b. Hasil pengisian angket pasca pelatihan

\begin{tabular}{|c|} 
Sangat \\
Setuju \\
Setuju \\
\\
\end{tabular}

Gambar 12. Grafik Pengetahuan tentang Geogebra 
Berdasarkan gambar 12 mengenai pengetahuan tentang geogebra didapat hasil yakni terdapat 5 peserta sangat setuju bahwa sudah mengetahui geogebra. Terdapat 8 orang setuju bahwa sudah mengetahui geogebra dan 3 orang kurang setuju sudah mengetahui tentang geogebra.

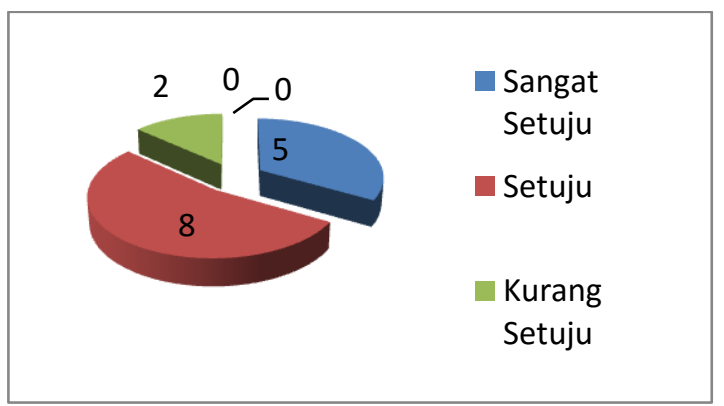

Gambar 13. Grafik Pengetahuan tentang Aplikasi screen Recorder

Berdasarkan gambar 13 mengenai pengetahuan tentang screen recorder didapat hasil yakni terdapat 5 peserta sangat setuju bahwa sudah mengetahui screen recorder. Terdapat 8 orang setuju bahwa sudah mengetahui screen recorder dan 2 orang kurang setuju sudah mengetahui tentang screen recorder.

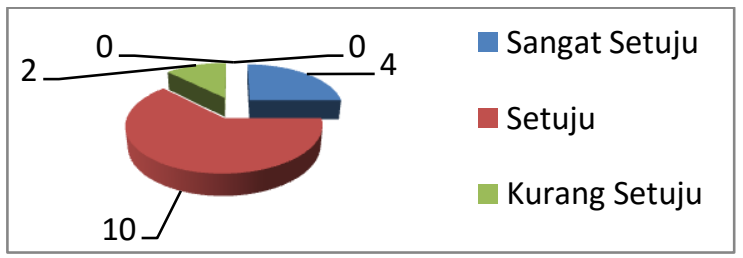

Gambar 14. Grafik kemampuan menggunakan Aplikasi Geogebra
Berdasarkan gambar 14 mengenai kemampuan menggunakan aplikasi geogebra didapat hasil yakni terdapat 4 peserta sangat setuju bahwa sudah mampu menggunakan aplikasi geogebra. Terdapat 10 orang setuju bahwa sudah mampu menggunakan aplikasi geogebra dan 2 orang kurang setuju bahwa sudah mampu menggunakan aplikasi geogebra

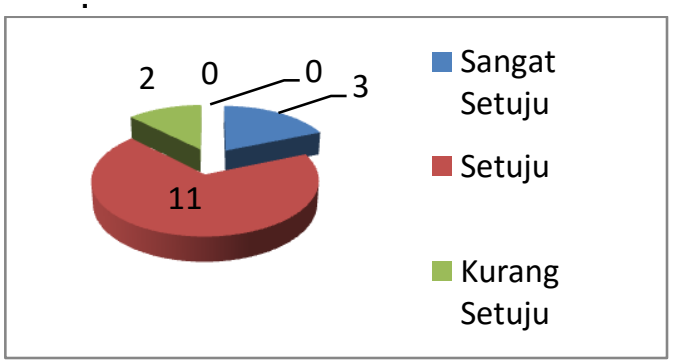

Gambar 15. Grafik kemampuan menggunakan Aplikasi Screen Recorder

Berdasarkan gambar 15 mengenai kemampuan menggunakan aplikasi screen recorder didapat hasil yakni terdapat 3 peserta sangat setuju bahwa sudah mampu menggunakan aplikasi screen recorder. Terdapat 11 orang setuju bahwa sudah mampu menggunakan aplikasi screen recorder dan 2 orang kurang setuju bahwa sudah mampu menggunakan aplikasi screen recorder. 


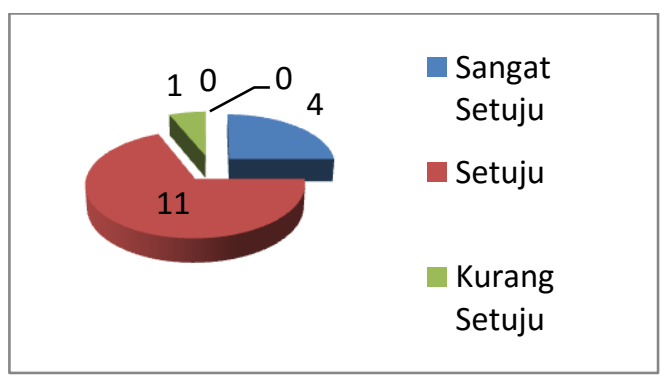

Gambar 16. Grafik kemampuan menggunakan Aplikasi Geogebra dalam pembuatan media Pembelajaran

Berdasarkan gambar 16 mengenai kemampuan menggunakan aplikasi Geogebra dalam pembuatan media pembelajaran didapat hasil yakni terdapat 4 peserta sangat setuju bahwa sudah mampu menggunakan aplikasi Geogebra dalam pembuatan media pembelajaran. Terdapat 11 orang setuju bahwa sudah mampu menggunakan aplikasi Geogebra dalam pembuatan media Pembelajaran dan 1 orang kurang setuju bahwa sudah mampu menggunakan aplikasi Geogebra dalam pembuatan media pembelajaran.

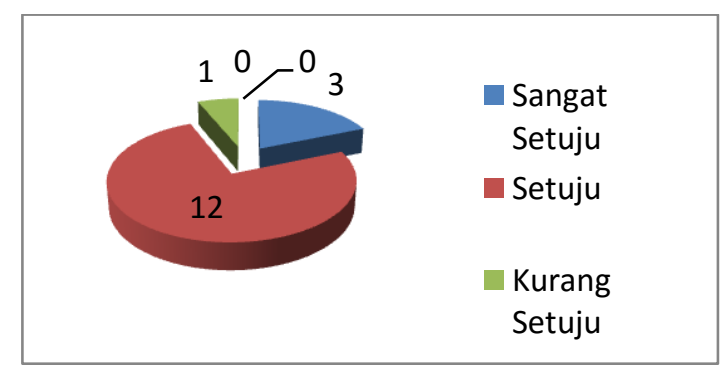

Gambar 17. Kemampuan

menggunakan aplikasi Screen

Recorder dalam Pembuatan media pembelajaran

\section{Berdasarkan gambar}

mengenai kemampuan menggunakan aplikasi screen recorder dalam pembuatan media Pembelajaran didapat hasil yakni terdapat 3 peserta sangat setuju bahwa sudah mampu menggunakan aplikasi screen recorder dalam pembuatan media Pembelajaran. Terdapat 12 orang setuju bahwa sudah mampu menggunakan aplikasi screen recorder dalam pembuatan media Pembelajaran dan 1 orang kurang setuju bahwa sudah mampu menggunakan aplikasi screen recorder dalam pembuatan media Pembelajaran.

c. Pembahasan

Berdasarkan hasil pre test dan post di atas, dapat disimpulkan sebagai berikut.

1) Pertama, terdapat peningkatan kemampuan pengetahuan terhadap geogebra. Pre test menunjukkan bahwa belum ada guru yang mengetahui tentang geogebra. Setelah pelatihan, semua guru telah memiliki pengetahuan tentang geogebra. Pengetahuan yang dimiliki tersebar dalam beberapa kondisi yakni 5 orang sangat setuju, 8 orang setuju dan 3 orang tidak setuju. Hal ini menunjukkan bahwa pengetahuan yang dimiliki masih beragam. Namun secara umum guru telah memiliki pengetahuan yang cukup tentang geogebra

2) Kedua, terdapat peningkatan kemampuan pengetahuan terhadap screen recorder. Pre test 
menunjukkan bahwa terdapat satu guru yang mengetahui tentang screen recorder. Setelah pelatihan, semua guru telah memiliki pengetahuan tentang screen recorder. Pengetahuan yang dimiliki tersebar dalam beberapa kondisi yakni 5 orang sangat setuju, 8 orang setuju dan 3 orang tidak setuju. Hal ini menunjukkan bahwa pengetahuan yang dimiliki masih beragam. Namun secara umum guru telah memiliki pengetahuan yang cukup tentang screen recorder.

3) Ketiga, terdapat peningkatan kemampuan penggunaan geogebra. Pre test menunjukkan bahwa tidak ada guru yang bisa menggunakan geogebra. Setelah pelatihan, semua guru telah memiliki kemampuan penggunaan geogebra. Pengetahuan yang dimiliki tersebar dalam beberapa kondisi yakni 4 orang sangat setuju, 10 orang setuju dan 2 orang tidak setuju. Hal ini menunjukkan bahwa kemampuan penggunaan aplikasi geogebra yang dimiliki masih beragam. Namun secara umum guru telah memiliki kemampuan penggunaan geogebra.

4) Keempat, terdapat peningkatan kemampuan penggunaan screen recorder. Pre test menunjukkan bahwa terdapat satu guru yang bisa menggunakan screen recorder.
Setelah pelatihan, semua guru telah memiliki kemampuan penggunaan screen recorder. Pengetahuan yang dimiliki tersebar dalam beberapa kondisi yakni 3 orang sangat setuju, 11 orang setuju dan 2 orang tidak setuju. Hal ini menunjukkan bahwa kemampuan penggunaan aplikasi screen recorder yang dimiliki masih beragam. Namun secara umum guru telah memiliki kemampuan penggunaan screen recorder.

5) Kelima, terdapat peningkatan kemampuan penggunaan geogebra dalam pembuatan media pembelajaran. Pre test menunjukkan bahwa tidak ada guru yang bisa menggunakan geogebra dalam pembuatan media pembelajaran. Setelah pelatihan, semua guru telah memiliki kemampuan penggunaan geogebra dalam pembuatan media pembelajaran. Pengetahuan yang dimiliki tersebar dalam beberapa kondisi yakni 4 orang sangat setuju, 11 orang setuju dan 1 orang tidak setuju. Hal ini menunjukkan bahwa kemampuan penggunaan aplikasi geogebra yang dimiliki masih beragam. Namun secara umum guru telah memiliki kemampuan penggunaan geogebra dalam pembuatan media pembelajaran.

6) Terdapat peningkatan kemampuan penggunaan screen recorder. Pre test menunjukkan bahwa terdapat 
satu guru yang bisa menggunakan screen recorder dalam pembuatan media pembelajaran. Setelah pelatihan, semua guru telah memiliki kemampuan penggunaan screen recorder dalam pembuatan media pembelajaran. Pengetahuan yang dimiliki tersebar dalam beberapa kondisi yakni 3 orang sangat setuju, 12 orang setuju dan 1 orang tidak setuju. Hal ini menunjukkan bahwa kemampuan penggunaan aplikasi screen recorder yang dimiliki masih beragam. Namun secara umum guru telah memiliki kemampuan penggunaan screen recorder dalam pembuatan media pembelajaran.

\section{KESIMPULAN}

Berdasarkan hasil dan pembahasan diatas, maka simpulan yang dpaat ditarik adalah sebagai berikut

1. Adanya peningkatan kemampuan guru dalam penggunaan aplikasi online open source geogebra untuk pembuatan media pembelajaran bidang matematika dan science. Hal ini terlihat dari pengetahuan geogebra yang pada awalnya $0 \%$ yang mengetahui menjadi $100 \%$ tahu. Ditinjau dari penggunaan geogebra yang pada awalnya $0 \%$ menjadi $100 \%$ bisa menggunakan. Ditinjau dari pembuatan media pembelajaran menjadi $100 \%$ bisa membuat.

2. Meningkatkan kemampuan guru dalam penggunaan aplikasi online perekaman layar computer utuk pembuatan media pembelajaran pada pelajaran ilmu sosial. Hal ini terlihat dari pengetahuan screen recorder yang pada awalnya $0 \%$ yang mengetahui menjadi 100\% tahu. Ditinjau dari penggunaan screen recorder yang pada awalnya $0 \%$ menjadi $100 \%$ bisa menggunakan. Ditinjau dari pembuatan media pembelajaran menjadi $100 \%$ bisa membuat.

\section{DAFTAR PUSTAKA}

Arbain, N \& Shukor, N.A. 2015. The effect of Geogebra on Students Achievement.Johor Baru: Elsevier Itd. Arifin, Z.

Erawati, N. K., Purwati, N. K. R., Putri, N. W. S. P., \& Wardika, I. W. G. (2021). Pelatihan Geogebra Sebagai Media Pembelajaran Inovatif. Jurnal Puan Indonesia, 2(2), 164-174.

Fitriyani, Wulan. 2014. Pengembangan Perangkat Pembelajaran Teorema Pythagoras Dengan Pendekatan Ideal Berbantuan Geogebra.Jurnal Riset Pendidikan Matematika. 1(2):268-283. Diakses tanggal 1 juli 2021

Mahmudi, Ali. 2011. Pemanfaatan GeoGebra dalam Pembelajaran Matematika.https://www.academ ia.edu/2137476/Pemanfaatan_G eoGebra_dalam_Pe mbelajara_Matematika. Diakses tanggal 1 juli 2021.

Peradhayana, Wayan Sauri. 2021. Perancangan Kain Endek 
Melalui Pembuatan Fungsi Kuadrat Pada Software Geogebra. Jurnal Edukasi Matematika dan Sains. Volume 10 nomor 1. https://ojs.mahadewa.ac.id/inde x.php/emasains/article/view/833. Tanggal akses 1 juli 2021

Peradhayana, Wayan Sauri. 2020. Perancangan Kain Endek Melalui Pembuatan Fungsi Linier Pada Software Geogebra. Jurnal Edukasi Matematika dan Sains. Volume 9 nomor 2. https://ojs.mahadewa.ac.id/inde x.php/emasains/article/view/834. Tanggal akses 1 juli 2021

Peradhayana, Wayan Sauri. 2020. Perancangan Kain Endek Melalui Pembuatan Fungsi Trigonometri Pada Software Geogebra. Jurnal Edukasi Matematika dan Sains. Volume 9 nomor 2. https://ojs.mahadewa.ac.id/inde x.php/emasains/article/view/832. Tanggal akses 1 juli 2021

Putra, I. K. A., Wardika, I. W. G., Putra, I. P. S. A., Putri, N. W. S., Setiawan, I. M. D., \& Peradhayana, W. S. (2021). Pembinaan kompetisi Sains Siswa Melalui Pemberdayaan Klub IImu Sosial. JMM (Jurnal Masyarakat Mandiri), 5(1), 266-
276.

Putri, N. W. S., \& Wardika, I. W. G. (2020a). Implementation TANDUR Learning Using GeoGebra Towards Student Learning Result Viewed from Independence Learning. JTAM (Jurnal Teori Dan Aplikasi Matematika), 4(2), 115-121.

Putri, N. W. S., \& Wardika, I. W. G. (2020b). Interaksi Model Pembelajaran Tandur Berbantuan Media Geogebra Terhadap Hasil Belajar Mahasiswa ditinjau dari Kemandirian Belajar. Paedagoria: Jurnal Kajian, Penelitian Dan Pengembangan Kependidikan, 11(2), 99-105.

Wardika, I. W. G., \& Putra, I. P. S. A. (2019). Pengaruh Model Pembelajaran Kooperatif Tipe STAD berbantuan GeoGebra Terhadap Hasil Belajar Program Linear ditinjau dari Pengetahuan Awal Mahasiswa. JOURNAL OF SONGKE MATH, 2(1), 23-34.

Wijayanti, N. W. E., Putri, N. W. S., Suryana, I. G. E., Suryati, K., Sepdyana, K., Wardika, I. W. G., \& Krisna, E. D. (2021). Pelatihan Bisnis Online Menggunakan Aplikasi Shopee. JMM (Jurnal Masyarakat Mandiri), 5(1), 206215. 